\title{
Luis María de Salazar, Ángel Laborde and the Defence of Cuba, 1825-9: A Study in Combined Leadership
}

\author{
Carlos Alfaro Zaforteza \\ King's College London
}

On 9 December 1824 the last Royalist army in the American continent was defeated at the plateau of Ayacucho. The battle caused the fall of the Viceroyalty of Peru and is generally considered the end of the Spanish American wars of independence. It is generally less well known that hostilities went on in the Gulf-Caribbean area for a further five years. Once free from Royalist forces in the mainland, the Colombian government started preparations for a combined attack, together with Mexico, on Cuba and Puerto Rico. The objective was twofold: to eliminate a serious threat to the independence of both states, and to end Spanish rule in America. The critical military element in this enterprise was seapower. This paper analyses the actions of two men who led the Spanish navy at that time; they succeeded in providing adequate defence for the island of Cuba in particularly difficult conditions. It is true that the United States, Britain and France opposed such an alteration of the Caribbean status quo. Yet it was not clear how far they were willing to go in this direction, nor if they would be able to act in time. The Colombian and Mexican governments, as well

How to cite this book chapter:

Zaforteza, C A. 2017, Luis María de Salazar, Ángel Laborde and the Defence of Cuba, 1825-9: A Study in Combined Leadership. In: Harding, R and Guimerá, A (eds.). Naval Leadership in the Atlantic World. Pp. 131-139. London: University of Westminster Press. DOI: https://doi.org/10.16997/book2.m. License: CC-BY-NC-ND 4.0 
as the Spanish, harboured serious doubts as to whether these powers could or would effectively deter patriot plans. The Spanish government, therefore, rightly assumed that it must rely on its own means.

Spanish historiography has largely ignored this achievement, even though it was arguably the most creditable performance put up by the navy during the Spanish AmericanWars of Independence. The two key personalities concerned were the Navy Minister, Luis María de Salazar, and the commander of the Apostadero de la Habana (Havana Station), Ángel Laborde. This paper is made up of three sections: the nature of the threat, the situation and main actors, and the response. Success was the result of effective leadership and close cooperation, despite the obstacle of distance - 4,000 nautical miles between Madrid and Havana, and the appalling state of the navy and the country.

\section{The threat}

When Britain recognised Buenos Aires, Colombia and Mexico, the Spanish government was concerned that they would enjoy easier access to credit. This was essential to acquire and operate a sizeable naval force. Colombian VicePresident Francisco de Paula Santander was especially sanguine about naval affairs. He planned to use the fleet to help Mexico take the fortress of San Juan de Ulúa and blockade or destroy the Spanish squadron in Havana. For this purpose, he purchased one ship of the line and one frigate from the Swedish navy and ordered two powerful frigates to be built in the United States. ${ }^{247}$ The Mexican government, for its part, fortuitously came into possession of the Spanish ship of the line Asia. In June 1825 the crew mutinied and went over to the insurgents. By September, as the Asia started on its long journey from Monterrey to Veracruz, the only units of any consequence in the port of Veracruz were a converted merchant frigate and two brigs, which had been acquired through a London firm. Mexico also had some minor vessels being built in the United States, and was in negotiations to buy a frigate and 84-gun ship from Sweden. ${ }^{248}$ These ships presented an imposing array, since it was assumed that they would soon be ready for combat. By comparison, the only major ships of the Havana squadron were two frigates.

Initially, difficulties in getting reliable intelligence caused confusion and alarm. In September the consul in New York reported on the ships being built locally for the patriots. The two Colombian 64-gun frigates were especially worrying; they were superior to anything the Spaniards had. A Swedish ship of the line had also arrived, to be converted into another large frigate. The Mexican government was erroneously reported to have another 64-gun frigate under construction and several minor vessels. ${ }^{249}$ Incoming information about the Patriots' capabilities was also unsettling. A report received in August 1825 stated that one of the big Colombian frigates would be ready in a month. Salazar hoped to have three frigates ready by the end of the year. He had originally 
planned to send two to Cuba, as escorts of a troop convoy, and leave one in metropolitan waters. Yet he could not afford to run the risk of an attack on the convoy; a Colombian squadron including the new ship was more than a match for the two frigates and a brig of the escort, so he chose to add a third frigate. The decision was difficult, as it meant leaving metropolitan waters with nothing larger than a sloop, but reinforcing Cuba was top priority. ${ }^{250}$ Almost simultaneously, another event raised the threat level. In September Laborde's last attempt to relieve San Juan de Ulúa failed. His force of two frigates, one sloop and two transports ran into a storm. Laborde's flagship, the Sabina, was dismasted and had to return to Havana. Although damaged, the rest carried on, but turned back without a fight when a Mexican squadron interposed itself between them and the fortress. The battered ships took more than a month to repair. During this time the Apostadero's largest serviceable units were two brigs. Cuba and its commerce were practically defenceless against naval attack. Of course, no ships were available for another relief expedition to San Juan de Ulúa, which finally surrendered in November. This caused an invasion panic in Cuba, dealt a heavy blow to Spanish morale and increased the sense of urgency about Cuba's defencelessness. In December Salazar received another piece of intelligence: the patriots expected to have a fleet of two ships of the line and seven frigates ready for action in a month's time. ${ }^{251}$

The difficulties which precluded the materialisation of these plans were not yet apparent in March 1826, when Mexico and Colombia concluded a formal treaty to constitute a combined fleet based at Veracruz. It was to be commanded by an American naval officer, David Porter, a hero of the War of 1812; operations were to start at the end of May. The main objective was to destroy the Havana squadron. ${ }^{252}$ Due to lack of resources, the whole plan started falling apart almost from the outset. Yet some time elapsed before the Spanish authorities realised it. The view from Madrid was gloomy; distance magnified the problem; the country had no effective allies and few resources to draw on.

\section{The situation and the men}

By 1825 Spain was an impoverished country, not yet recovered from the ravages of the war against Napoleon (1808-14). The staggering foreign debt, the end of the American silver supply and recurrent political strife precluded reconstruction. The navy's condition was no better. During the French invasion most ships were disarmed and the crews fought ashore; the dockyards were despoiled of every single valuable item, and the ships were allowed to decay for lack of maintenance. After the war, no ships were available to fight the American insurgents. In 1817 the government had to resort to purchasing a squadron of five ships of the line and three frigates from Russia. By mid-1825 not a single ship of the line was in commission, and the number of frigates was reduced to three. Only Cádiz Dockyard, the main naval base, was able to 
support this meagre force; new construction was out of the question. Only the personnel remained. A small core of naval officers had preserved their skills through continuous service afloat and action against the insurgents. However, they were demoralised by the old, worn-out materiel, bleak career prospects and erratic pay. In those years, the navy got only a fraction of its official budget. The resulting malaise added to Salazar's material difficulties.

Only the Apostadero de la Habana had a regular budget and punctually paid its personnel. It was financed by the Cuban treasury, but the war brought new commitments, such as the relief of the fortress of San Juan de Ulúa, on the Mexican coast. By 1825 the island's income could barely meet ordinary expenses, let alone wartime obligations. Help from the worse-off metropolitan treasury was out of the question. The dockyard, which had built so many ships in the previous century, was capable of only limited repair work; it lacked a dry dock, had a poor supply of naval stores, and labour costs in Havana were much higher than in the Peninsula. Moreover, the Apostadero's naval administration was notoriously wasteful. Additionally, the island's naval budget was burdened with the salaries of many retired and half-pay officers, which left little for materiel expenses. In order to protect Cuban commerce, the island's trading community had contributed generous sums to make up for the deficit, but without noticeable results.

Even if all of the station's ships were kept fully operational, 11 ships were far from enough to defend Cuba and Puerto Rico against invasion, escort relief convoys to San Juan de Ulúa and protect Spanish trade in the Gulf-Caribbean area. The station's commander, Brigadier Miguel Gastón, considered that an adequate force should be made up of 26 ships, which meant more than doubling the cost (see table).

The man in charge of coping with this situation was the navy minister, Luis María de Salazar y Salazar (1758-1838). He started his career as a naval officer, but soon ill health forced him to abandon service afloat. Nevertheless, his work as a naval administrator was outstanding. In 1792 he was called to serve in the Navy Ministry, under his relative General Mazarredo, one of the most

\begin{tabular}{|c|c|c|}
\hline & Existing & Required \\
\hline Ships of the line & none & 1 \\
\hline Frigates & 2 & 5 \\
\hline Sloops & 3 & 3 \\
\hline Brigs & 4 & 10 \\
\hline Schooners & 2 & 7 \\
\hline Total & 11 & 26 \\
\hline Annual cost (pesos) & 650,000 & $1,500,000$ \\
\hline
\end{tabular}

Table 1: Spanish naval strength in Cuba, March $1825 .^{253}$ 
influential naval officers at the turn of the century. In 1803 he was appointed Intendant of Ferrol Dockyard, where he continued to hone his skills. During the War of Independence, he was already so highly regarded that he was appointed finance minister of the Regency and later governor of Seville. ${ }^{254}$ After the war, Salazar served his first term as navy minister (1814-16). In 1820 the Liberals offered him the post, which he declined, but he accepted it from the Absolutists three years later. During his second term (1823-32) he ably ran the service for almost ten years under extreme penury and complex political circumstances. He enjoyed the respect of his fellow cabinet members and most of the officer corps. Though Salazar was a conservative, but not a recalcitrant one, most of the latter were Liberals. He was thus one of the few who could liaise with practically everybody, which made his work much easier.

Ángel Laborde y Navarro (1772-1834) was the commander of the Apostadero de la Habana. He arrived in the Caribbean in 1820, to take command of a squadron based at Puerto Cabello, until the town was evacuated in 1823 . He was then based at Havana, as deputy commander of the Apostadero. During these years he earned a reputation as a proactive, successful leader among friends and foes. Once he was appointed commander of the Havana Station he reversed traditional practice: he spent most of the time afloat, while his deputy took care of the dockyard and logistic support. Laborde always made sure that his men were punctually paid and well cared for, but he also expected them always to do their duty.

Two examples illustrate this attitude. He would select only the ablest men in critical posts. An officer who had served under Laborde, and was in half-pay, managed to get a commission as commander of one of his frigates through his political connections in Madrid; he hoped to get his full pay again, which would allow him to maintain adequately his nine-child family. Laborde, who knew him well, rejected the appointment for two reasons. The officer had some ailments that impaired his health; his professional skills and knowledge lagged behind those of his colleagues, because he had shown no interest in nurturing them. ${ }^{255}$ This behaviour does not mean that he was not humane. During the two heavy storms cited below, officers lost most of their personal belongings, including expensive items such as chronometers and other navigation instruments. Presumably on Laborde's advice, the Havana Intendant provided the money to buy replacements, and Salazar approved the measure. ${ }^{256}$ In the distance, Salazar had to rely on Laborde's professional judgement and leadership skills; it seems that he never regretted it.

\section{The solution}

Salazar's response to the threat was to appoint the right man to lead the Havana squadron, trust him and provide him with the necessary materiel. His choice of Laborde was not exempt from controversy. The latter's capabilities 
were evident, but, as a captain, he was too junior for the post. Salazar allayed this difficulty by lowering the required rank, ostensibly to save expenses. In doing this he alienated several officers who believed that they were entitled to the post. Further, Gastón had not finished his full term; he was dismissed because the other island authorities, notably the Captain General, were dissatisfied with him. ${ }^{257}$ What Salazar expected from Laborde was not only first-class operational command, but also the effective implementation of administrative reform. To optimise operational readiness, all non-essential expenses were to be cut. This included sending back redundant personnel who had taken refuge there during the Liberal period (1820-3) to secure their pay. ${ }^{258}$ Laborde's appointment met with wide approval in Cuba and boosted the morale of the Apostadero's personnel. He had a rapport not only with Salazar, but with the other Cuban authorities, which made for smooth, close collaboration.

Shortage of ships in the Peninsula posed larger difficulties. The Captain General and the Intendant, as well as Laborde, asked for naval reinforcements to be sent urgently; to start with, they needed one ship of the line and two frigates. ${ }^{259}$ The few ships still worth repairing needed substantial work to make them serviceable again. However, before this was possible the dockyards themselves had to be refurbished, supplied with stores and provided with skilled labour. There was neither money nor time to do this; only the bare essentials could be restored. The dry docks at Cádiz and the channel that linked them with the harbour were silted. To refit the two ships of the line they had to be dredged and their doors repaired. ${ }^{260}$ Cádiz was the main naval base of the fleet; Ferrol and Cartagena were simply abandoned. To have the ships repaired within time and cost, Salazar resorted to private contractors. They used the dockyards' existing facilities, brought their own equipment, materials and personnel, and did the job. ${ }^{261}$ In this way Salazar obviated the need to restore the costly dockyard infrastructure; he had only to care about paying for each individual task.

An unexpected circumstance produced the necessary funds: a failed crop threatened famine in Andalusia and the Mediterranean coastal areas. To prevent this, the government temporarily lifted the ban on foreign grain. The duties levied on the import licences were allocated to the navy. Had he not benefited from this windfall, the resourceful Salazar would presumably have come up with a solution. Thanks to this fortuitous event, he was able to kickstart the construction of the frigates Iberia and Lealtad, and begin refit work on the ships of the line Guerrero and Soberano. ${ }^{262}$ The first two had been laid down at Ferrol Dockyard in 1821, but construction had stopped for lack of money; Guerrero and Soberano were old eighteenth-century 74-gun ships which had been lying in utter neglect for years at Ferrol Dockyard.

Due to the extreme penury of the treasury, competition for money among the different government departments was intense; corruption was rife at all levels, and the state administrative machinery was in disarray. In these circumstances it was not unusual for sizeable amounts to be diverted from their 
original purpose, or simply disappear. Salazar knew this only too well to trust the existing bureaucracy. Navy paymasters in the port towns were supposed to collect the proceeds of the said import licences and transfer them directly to the contractors. Salazar issued strict orders for the money to be transferred directly to Madrid instead. There it was to be kept by the Navy Paymaster General in a special safe with two keys (the second was to be kept by another trusted official) in his office; Salazar was to be instantly informed of every movement in and out. To keep a permanent watch on the safe, the paymaster was instructed, as well, to stay overnight in the building, together with a naval infantry guard of hand-picked men. ${ }^{263}$ This episode illustrates the administrative chaos and the feeling of insecurity in Spain at the time. Salazar also had to cope with the resulting malaise.

After 1808 the number of ships and the naval budget were greatly reduced, but the Navy List was still packed with officers. Although only a small proportion could actually be employed, the rest were still entitled to their salaries. Salazar found out that the pay distribution was haphazard; some inactive officers were getting paid more regularly than their colleagues in active service. The latter were not getting more than six payments a year. Occasionally, some officers were reluctant to sail unless they were paid some of their arrears; unlike seamen, they had to buy their own food. Salazar dealt with this comparative injustice through a tighter control of the paymasters and a clear set of priorities. He made sure that personnel serving afloat were paid punctually. A comparative grievance, and a major cause of low morale and lack of discipline, was thus removed. ${ }^{264}$ These reforms in the materiel and the personnel were indispensable to supply Laborde with the necessary means for action.

In December 1825 three frigates and a convoy arrived in Havana. Shortly after, the frigates Sabina and Casilda, from the Apostadero de La Habana, were repaired after the damage they sustained trying to relieve San Juan de Ulúa. Hence, by the beginning of 1826, Laborde was able to deploy a squadron of five frigates, soon reinforced by a ship of the line. At last he could conduct the offensive strategy that he was used to. ${ }^{265}$ As soon as the Guerrero (74) joined his squadron, in March 1826, he sailed to Cartagena (Colombia), where the enemy fleet lay. It was made up of one ship of the line, three frigates, two sloops and four minor warships, but the ship of the line and one frigate were not combatready, and there were not enough personnel to man the rest. ${ }^{266}$ The Colombian squadron, therefore, was unable to leave the harbour and meet Laborde's challenge. The Spanish fleet was left free to sail along the Venezuelan coast, to encourage Royalist guerrillas and politically destabilise the country. This political mission was of the utmost importance, both to keep the enemy busy and as part of a plan to restore Spanish rule. Four months later Laborde set sail again with the same objective. General Páez, the governor of Venezuela, had rebelled against the central government at Bogotá; these political dissensions made the country more vulnerable to Royalist action. Laborde was to collect a 
battalion and money in Santiago de Cuba to support the Venezuelan Royalists. Yet the operation was aborted by an unexpected event. As the squadron sailed through the Bahama Channel, it ran into a hurricane. The ships were dispersed and heavily damaged; they limped back to Havana under jury rig. ${ }^{267}$ Due to the limited facilities of Havana Dockyard, the repairs took two months. The large number of masts and spars required were not available in Cuba, and had to be ordered from the United States. In the meantime, Commodore David Porter, in the service of the Mexican navy, seized the opportunity to harass Cuban commerce. He took advantage of the benevolent neutrality of the US government to base his squadron at Key West, but Spanish forces blockaded him there and captured his best ship. ${ }^{268}$

The next time that Laborde received demands to support Royalist guerrillas in Venezuela, he waited until December, when the hurricane season was over. He cruised off the Venezuelan coast until February, but was unable to establish contact. This time his force was reduced to the Guerrero, Iberia and a brig. He did not expect substantial opposition now that the real capabilities of the enemy were known. By 1827 the shortage of officers, seamen and money had become so acute that the Colombian navy had had to disarm most of its ships; it was no longer a combat-worthy force. The Mexican navy experienced the same difficulties. After a long journey around Cape Horn, the ship of the line Congreso Mexicano (formerly the Spanish Asia) finally arrived in Veracruz, only to be decommissioned. ${ }^{269}$ On the other hand, the Apostadero de la Habana went from strength to strength.

In 1828 Salazar sent the ship of the line Soberano and the frigate Restauración, and the Cuban treasury could now comfortably support its increasing naval strength. The naval superiority thus achieved enabled the setting up of regularly scheduled convoys between Havana and Cádiz without unduly weakening the defence of Cuba. Additionally, a fully fledged expedition against Mexico was planned for the following year. The landing at Tampico in July 1829 was supported by just one ship of the line and two frigates, just a fraction of the station's total strength. The enemy navies lay disarmed in port. With enough ships and soldiers in Cuba, and no opposition at sea, another attempt at the re-conquest of Mexico was planned for 1830. Salazar even sent a third ship of the line. However, the outbreak of revolution in France diverted the Spanish government's attention away from America. Colombia and Mexico were also absorbed by internal troubles: they had neither the capability nor the intention to continue hostilities. For all practical purposes, the war was finished.

\section{Conclusions}

The successful leadership displayed by Salazar and Laborde was instrumental in preserving Spanish rule in Cuba and Puerto Rico for the rest of the century. The former's acumen in selecting the latter, trusting him, and providing 
him with the ships and men to do the job, succeeded in the face of apparently insurmountable difficulties. The legacies of Salazar and Laborde, in naval policy and operational command respectively, exerted considerable influence in nineteenth-century naval policy. The new emphasis on merit and results introduced a new ethos. The excessive forbearance of the previous-century establishment towards an officer's failings or misconduct was at an end. During the reign of Queen Isabel II (1833-68), able administrators created an effective steam navy, run by experienced, competent officers, which effectively contributed to the defence of Cuba. Admiral Castro Méndez Núñez (1824-69) was the outstanding officer of this period. A worthy successor of Laborde, he ably led his men to victory in Mindanao, Santo Domingo and Callao. 
